\title{
Visual dysfunction, but not retinal thinning, following anti-NMDA receptor encephalitis
}

\section{OPEN}

Alexander U. Brandt, MD

Timm Oberwahrenbrock, $\mathrm{PhD}$

Janine Mikolajczak, MSc Hanna Zimmermann,

MEng

Harald Prüss, MD

Friedemann Paul, MD

Carsten Finke, MD

Correspondence to

Dr. Brandt:

alexander.brandt@charite.de

\section{ABSTRACT}

Objective: To assess structural and functional changes in the afferent visual system following anti-NMDA receptor (NMDAR) encephalitis.

Methods: In this cross-sectional study including 31 patients after acute NMDAR encephalitis and matched healthy controls, visual function was assessed as high-contrast visual acuity using Early Treatment Diabetic Retinopathy Study charts and low-contrast sensitivity using Functional Acuity Contrast Test. Retinal changes were measured using optical coherence tomography with assessment of peripapillary retinal nerve fiber layer (pRNFL) and macular intraretinal layer thicknesses. Residual clinical impairment was described using the modified Rankin Scale.

Results: High-contrast (logMAR $0.02 \pm 0.14$ vs $-0.09 \pm 0.14, p<0.001)$ and low-contrast (area under the curve $1.89 \pm 0.21$ vs $2.00 \pm 0.26, p=0.039$ ) visual acuity were reduced in patients in comparison to healthy controls. More severely affected patients performed worse in visual acuity testing than patients with good recovery (logMAR $-0.02 \pm 0.11$ vs $0.08 \pm 0.17$, $p=0.030)$. In contrast, patients did not differ from matched healthy controls in pRNFL or in thickness of intraretinal layers, including the ganglion cell complex, the inner nuclear layer, the outer nuclear and plexiform layers, and the photoreceptor layer.

Conclusions: After acute NMDAR encephalitis, patients have mild visual dysfunction in comparison to matched healthy controls, while retinal structure appears unaltered. These observations could point to an impairment of anterior or posterior visual pathway NMDAR function that is similar to dysfunction of NMDAR in cerebral cortex and subcortical structures. Alternatively, residual cognitive impairment might reduce visual function. Neurol Neuroimmunol Neuroinflamm 2016;3: e198; doi: 10.1212/NXI.0000000000000198

\section{GLOSSARY}

AQP4 = aquaporin-4; AUC = area under the curve; ETDRS = Early Treatment Diabetic Retinopathy Study; FACT = Functional Acuity Contrast Test; $\mathbf{G C C}=$ ganglion cell complex; GEE = generalized estimating equation; lgG = immunoglobulin G; $\mathbf{I N L}=$ inner nuclear layer; $\mathbf{M O G}=$ myelin oligodendrocyte glycoprotein; $\mathbf{m R S}=$ modified Rankin Scale; $\mathbf{N M D A R}=$ NMDA receptor; $\mathbf{O C T}=$ optical coherence tomography; $\mathbf{O P N L}=$ outer plexiform and nuclear layer; $\mathbf{P R L}=$ photoreceptor layer; pRNFL = peripapillary retinal nerve fiber layer; $\mathbf{V A}=$ visual acuity .

Anti-NMDA receptor (NMDAR) encephalitis is an acute disorder of the CNS caused by antibodies against the extracellular N-terminal domain of the receptor's NR1 subunit. ${ }^{1-3}$ Patients develop a severe neuropsychiatric syndrome with amnesia, behavioral changes, psychosis, dyskinesia, and epileptic seizures, and may also have hypoventilation and decreased consciousness. ${ }^{4}$ Eighty percent of patients recover well, achieving modified Rankin Scale (mRS) scores between 0 and 2, although many patients continue to have cognitive deficits, mostly in the form of memory and executive function impairment. ${ }^{5,6} \mathrm{MRI}$ appears normal in $25 \%-50 \%$ of patients with acute NMDAR encephalitis, but can show mild and transient T2/fluid-attenuated inversion recovery hyperintensities in the hippocampus, brainstem, and cerebral white and gray

\footnotetext{
From the NeuroCure Clinical Research Center (A.U.B., T.O., J.M., H.Z., F.P.) and Department of Neurology (H.P., F.P., C.F.), CharitéUniversitätsmedizin Berlin; German Center for Neurodegenerative Diseases (DZNE) (H.P.), Berlin; and Berlin School of Mind and Brain (C.F.), Humboldt-Universität zu Berlin, Germany.

Funding information and disclosures are provided at the end of the article. Go to Neurology.org/nn for full disclosure forms. The Article Processing Charge was paid by the authors.

This is an open access article distributed under the terms of the Creative Commons Attribution-NonCommercial-NoDerivatives License 4.0 (CC BY-NC-ND), which permits downloading and sharing the work provided it is properly cited. The work cannot be changed in any way or used commercially.
} 
matter. ${ }^{7}$ In contrast, lasting functional and white matter brain changes, as well as persisting hippocampal damage associated with memory impairment, were observed recently in patients recovering from NMDAR encephalitis. ${ }^{8,9}$

Retinal neurons express NMDAR, which are-among others - relevant for contrast sensitivity, ${ }^{10}$ and might be potential targets in acute NMDAR encephalitis. Specifically, mRNA for NMDAR subunits or functional NMDAR expression have been shown in horizontal cells, ${ }^{11,12}$ amacrine cells, ${ }^{13-16}$ and ganglion cells in several vertebrates. ${ }^{13,14,17-22}$ Visual dysfunction is not among the common symptoms of acute NMDAR encephalitis; however, given the frequently severe presentation, visual symptoms might not attract attention or might be difficult to assess during the acute disease stage. Moreover, an overlap with demyelinating syndromes was recently described in a subgroup of patients with NMDAR encephalitis, many of them with visual deficits that were mostly caused by optic neuritis. ${ }^{23,24}$ The objective of this study was to investigate the retina for potential structural damage after NMDAR encephalitis as well as potential visual function changes.

METHODS Patients and controls. For this cross-sectional observational study, patients post-recovery from the acute disease stage of NMDAR encephalitis were recruited from the outpatient clinic of the Department of Neurology of CharitéUniversitätsmedizin Berlin. Inclusion criteria were diagnosis of previous NMDAR encephalitis and ability to give informed consent. Diagnosis was based on immunoglobulin G (IgG) NMDAR antibodies in patients' CSF and characteristic clinical presentation. Residual clinical impairment was evaluated using the mRS. ${ }^{25}$ Two patients presented with a demyelinating overlap syndrome; both tested seronegative for aquaporin-4 (AQP4) and myelin oligodendrocyte glycoprotein (MOG) antibodies. Twenty-five patients had been included in previous studies investigating functional and structural MRI changes. ${ }^{8,9}$ Healthy controls were randomly selected from the NeuroCure Clinical Research Center's research database and matched for age and sex.

Standard protocol approvals, registrations, and patient consents. The study was approved by the internal ethics review board of the Charité-Universitätsmedizin Berlin and was conducted in conformity with the 1954 Declaration of Helsinki in its currently applicable version. All study participants gave informed written consent.

Visual function. Visual function testing was performed with Optec 6500 (Stereo Optical Inc., Chicago, IL). High-contrast visual acuity (VA) was measured using Early Treatment Diabetic Retinopathy Study (ETDRS) charts at simulated 20-feet distance. Low contrast sensitivity was measured using Functional Acuity Contrast Test (FACT) charts at photopic $(85 \mathrm{~cd})$ conditions at simulated 20 feet distance. FACT was performed at 5 different spatial frequencies. Contrast sensitivities were then combined as area under the curve (AUC) over all spatial frequencies, as previously described. ${ }^{26}$ All tests were performed monocularly for both eyes with habitual refractive error correction. One VA measurement from 1 eye and 3 FACT measurements from 3 eyes from 2 patients were not included in the analysis due to time constrains or technical issues.

Optical coherence tomography (OCT). Peripapillary retinal nerve fiber layer thickness ( $\mathrm{pRNFL}$ ) and macular volume scans were acquired with a Heidelberg Spectralis spectral-domain OCT (Heidelberg Engineering, Heidelberg, Germany) as previously described. ${ }^{27}$ pRNFL thickness was determined using the device's standard protocol from a $12^{\circ}$ circular scan around the optic nerve head with activated eye tracker. The maximum 100 averaging frames in the automatic real-time mode (ART) were used whenever possible. Macular volume was acquired using a custom protocol focusing on the fovea (61 vertical slices [B scans], scanning angle of $30^{\circ} \times 25^{\circ}$, resolution $768 \mathrm{~A}$ scans per B scan, and ART 13). A second operator checked all scans for correct centering, sufficient signal strength, and segmentation based on the OSCAR-IB criteria. ${ }^{28}$ One patient had only 1 eye measured; 3 scans ( 2 pRNFL and 1 macular volume scan) from 3 patients, as well as 2 pRNFL scans from 2 healthy controls, did not pass quality control, leading to exclusion of these scans from data analysis.

Intraretinal segmentation data were taken from beta software (Heidelberg Eye Explorer V1.8.6.0 with Spectralis Viewing Module V6.0.0.2). This software automatically detects boundaries between retinal layers. All automated segmentation results were manually sighted and corrected where necessary by an experienced grader. After the intraretinal segmentation, the ganglion cell complex (GCC), consisting of retinal nerve fiber, ganglion cell, and inner plexiform layers, the inner nuclear layer (INL), the combined outer plexiform and nuclear layer (OPNL), and the photoreceptor layer (PRL) were analyzed as volume within the standard $6 \mathrm{~mm}$ ETDRS ring around the fovea.

Statistical analysis. Data are presented as mean \pm SD unless otherwise noted. OCT and visual function measurements were compared between patients with NMDAR encephalitis and healthy controls using generalized estimating equation (GEE) models with the respective OCT parameter from both eyes of each subject as dependent variable and group (healthy controls vs patients) as independent variable, correcting for age. GEE were also used to analyze a potential visual function association with mRS. Working correlation matrix was set to Exchangeable, accounting for within-subject intereye correlations. Age between groups was compared using a nonparametric MannWhitney $U$ test. Statistical significance was achieved at $p<$ 0.05 . No previous sample size calculation was performed and significance levels were not corrected for multiple comparisons. The study should therefore be considered exploratory. All statistical tests were performed with R Project 3.1.3 using package geepack 1.2-0. ${ }^{29}$

RESULTS Thirty-one patients with NMDAR encephalitis ( $28 \mathrm{female} / 3$ male, mean age $28.7 \pm$ 8.9 years) were included in this study and compared to matched healthy controls ( 28 female/3 male, 28.6 \pm 8.0 years). The sex match was exact; age did not 
differ between the groups $(p=0.889)$. Patients had a median mRS of 1 (range $0-3$ ). Seventeen patients displayed no or only mild residual clinical impairment (mRS $=0$ or 1$)$, while 14 patients were clinically impaired $(m R S \geq 2)$. A detailed description of the $\mathrm{mRS}$ scores and treatment medication is given in table 1.

VA was reduced in patients with NMDAR encephalitis in comparison to matched healthy controls ( $\log$ MAR $0.02 \pm 0.14$ vs $-0.09 \pm 0.14, p<$ 0.001 ; table 2 and figure 1 ). Moreover, FACT was lower in patients (AUC $1.89 \pm 0.21$ vs $2.00 \pm 0.26$, $p=0.039$; table 2 and figure 1 ). The mean scores of all 5 spatial frequencies (A-E) in FACT testing were decreased in patients compared to controls, but only the 3 highest frequencies $(\mathrm{C}-\mathrm{E})$ reached significance (A: $p=0.263, \mathrm{~B}: p=0.404, \mathrm{C}: p=0.029, \mathrm{D}: p<$ 0.001 , E: $p=0.014$ ). Patients with no or only mild clinical impairment ( $\mathrm{mRS}=0$ or $1, \mathrm{n}=17$ ) performed better than patients with higher disability

\begin{tabular}{|c|c|c|}
\hline \multirow[t]{2}{*}{ Table 1} & \multicolumn{2}{|c|}{$\begin{array}{l}\text { Detailed description of patients with } \\
\text { NMDA receptor encephalitis }\end{array}$} \\
\hline & & Values \\
\hline \multicolumn{3}{|c|}{ Modified Rankin Scale score } \\
\hline 0 & & 9 \\
\hline 1 & & 8 \\
\hline 2 & & 12 \\
\hline 3 & & 2 \\
\hline \multicolumn{3}{|c|}{ Delay between disease onset and study, mo } \\
\hline Mean & & 30.4 \\
\hline SD & & 21.1 \\
\hline Minimu & & 3.0 \\
\hline Maximı & & 82.0 \\
\hline \multicolumn{3}{|l|}{ Relapse } \\
\hline No & & 29 \\
\hline Yes & & 2 \\
\hline \multicolumn{3}{|c|}{$\begin{array}{l}\text { Immunosuppressive treatment (multiple } \\
\text { selections possible) }\end{array}$} \\
\hline Steroid & & 28 \\
\hline Steroid & ral) & 13 \\
\hline Immunc & bulins & 15 \\
\hline Plasma & hange & 16 \\
\hline Rituxim & & 7 \\
\hline Cyclop & shamide & 5 \\
\hline Azathic & & 3 \\
\hline Immunc & sorption & 2 \\
\hline Mycopl & late mofetil & 1 \\
\hline Bortez & & 1 \\
\hline \multicolumn{3}{|c|}{ Chronic immunosuppression at study time } \\
\hline Methot & & 2 \\
\hline
\end{tabular}

$(\mathrm{mRS} \geq 2, \mathrm{n}=14)$ in high-contrast VA testing $(\operatorname{logMAR}-0.02 \pm 0.11$ vs $0.08 \pm 0.17$; GEE $\mathrm{B}=-0.10, \mathrm{SE}=0.05, p=0.030$ ), but there was no group difference in low-contrast FACT testing $(p=0.58)$.

Patients and controls did not differ in retinal layer thickness measurements. Peripapillary RNFL, macular GCC, INL, OPNL, and PRL were all in the range of matched healthy controls (table 2, figure 2).

The 2 patients with overlapping demyelinating syndromes were not outliers in terms of highcontrast VA testing (case 1: logMAR both eyes = 0.1 ; case $2: \log \mathrm{MAR}$ right eye $=0.1$ and $\log \mathrm{MAR}$ left eye $=-0.1$ ) or in terms of low-contrast VA testing (case 1: AUC right eye $=1.58$ and AUC left eye $=1.17$; case 2 : AUC both eyes $=2.15$ ) . Furthermore, statistical testing for OCT parameter differences remained negative after exclusion of both patients with overlapping demyelinating syndromes (data not shown).

DISCUSSION We report mild reduction of highand low-contrast VA in patients after NMDAR encephalitis, which-although still in the range of normative values - was lower than in matched healthy controls. Importantly, more severely affected patients had worse high-contrast VA than patients with good clinical recovery. In contrast, we observed no structural retinal damage.

This comprehensive assessment of visual function after NMDAR encephalitis complements recent reports on visual dysfunction in affected patients. ${ }^{30-32}$ A case report described severely reduced VA (20/125, right eye; 20/50, left eye) in a patient with NMDAR encephalitis that gradually normalized during recovery. ${ }^{32}$ This deficit was accompanied by impaired higher-order visual functions, e.g., reduced color sensation and face recognition. Impaired VA and optic neuritis were also reported in patients with NMDAR encephalitis and overlapping demyelinating syndromes. ${ }^{23,24}$ Interestingly, antibodies to AQP4 and MOG were detected in most of these patients in addition to NMDAR antibodies. MOG antibodies were also found in a patient who had developed optic neuritis with optic disc swelling during NMDAR encephalitis relapse. ${ }^{31}$ While these latter studies observed visual impairment in patients with overlapping syndromes, we here report impaired VA in isolated NMDAR encephalitis without evidence of concomitant optic neuritis or other ophthalmic disease. Only 2 patients presented with a demyelinating overlap syndrome in our cohort, and both were seronegative for AQP4 and MOG antibodies.

Given the normal-appearing retinal structure in patients, we propose 2 candidate mechanisms for 


\begin{tabular}{|c|c|c|c|c|c|c|c|c|c|c|c|}
\hline \multirow[t]{3}{*}{ Table 2} & \multicolumn{11}{|c|}{ Optical coherence tomography and visual function measurements } \\
\hline & \multicolumn{4}{|c|}{ NMDAR-E } & \multicolumn{4}{|l|}{$\mathrm{HC}$} & \multicolumn{3}{|l|}{ GEE } \\
\hline & Mean & SD & Min & Max & Mean & SD & Min & Max & B & SE & p Value \\
\hline VA, logMAR & 0.02 & 0.14 & -0.2 & 0.5 & -0.09 & 0.14 & -0.2 & 0.5 & 0.12 & 0.03 & $<0.001$ \\
\hline FACT, AUC & 1.89 & 0.21 & 1.24 & 2.20 & 2.00 & 0.26 & 0.67 & 2.28 & -0.11 & 0.05 & 0.039 \\
\hline pRNFL, $\mu \mathrm{m}$ & 99.0 & 8.4 & 85.0 & 115.0 & 99.9 & 9.2 & 79.0 & 120.0 & -0.73 & 2.14 & 0.73 \\
\hline $\mathrm{GCC}, \mathrm{mm}^{3}$ & 2.91 & 0.18 & 2.55 & 3.37 & 2.95 & 0.20 & 2.54 & 3.44 & -0.04 & 0.05 & 0.40 \\
\hline $\mathrm{INL}, \mathrm{mm}^{3}$ & 0.95 & 0.05 & 0.82 & 1.07 & 0.95 & 0.05 & 0.82 & 1.05 & -0.005 & 0.012 & 0.70 \\
\hline OPNL, mm³ & 2.55 & 0.17 & 2.20 & 2.84 & 2.55 & 0.16 & 2.18 & 2.89 & -0.01 & 0.04 & 0.87 \\
\hline $\mathrm{PRL}, \mathrm{mm}^{3}$ & 2.24 & 0.05 & 2.10 & 2.35 & 2.24 & 0.06 & 2.12 & 2.37 & 0.004 & 0.013 & 0.75 \\
\hline
\end{tabular}

Abbreviations: AUC = area under the curve; $\mathrm{B}=$ coefficient; FACT = Functional Acuity Contrast Test; GCC = ganglion cell complex; GEE = generalized estimation equation models; $\mathrm{HC}=$ healthy controls; INL = inner nuclear layer; NMDAR-E = NMDA receptor encephalitis; OPNL = outer plexiform and nuclear layer; $\mathrm{PRL}=$ photoreceptor layer; $\mathrm{pRNFL}$ = peripapillary retinal nerve fiber layer; $\mathrm{VA}=$ visual acuity.

the underlying pathophysiology of the observed mild visual function loss. First, as several retinal neuron subtypes express NMDAR, the afferent visual system, including the retina, might be affected directly. mRNAs encoding NMDA subunits are expressed predominantly in the inner retina. ${ }^{33}$ In the INL, horizontal cells ${ }^{11,12}$ and amacrine cells express NMDAR. ${ }^{13-16}$ Both cell types are interneurons, which integrate signals from photoreceptors before they are propagated to retinal ganglion cells. Moreover, ganglion cells have been shown to express functional NMDAR in several vertebrates. ${ }^{13,14,17-22}$ The above studies suggest a role of NMDAR in orchestrating the excitatory synapse and, more specifically, in modulating contrast sensitivity. ${ }^{10}$ In our study, all OCT retinal layer measurements were similar in patients and healthy controls, arguing against substantial structural damage or neurodegeneration of the retina. Arguably, functional changes could also be based on ultrastructural, synaptic alterations, which cannot be

Figure 1 Visual acuity differences
A. High contrast visual acuity

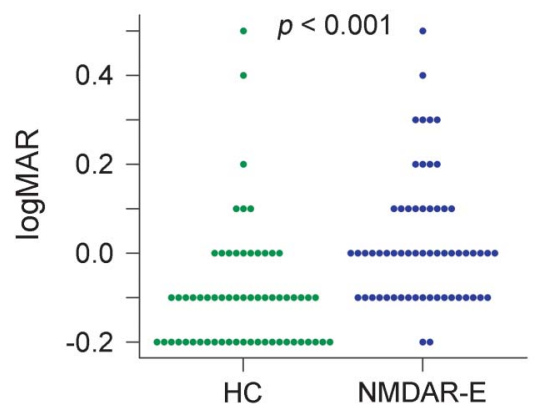

B. Low contrast FACT

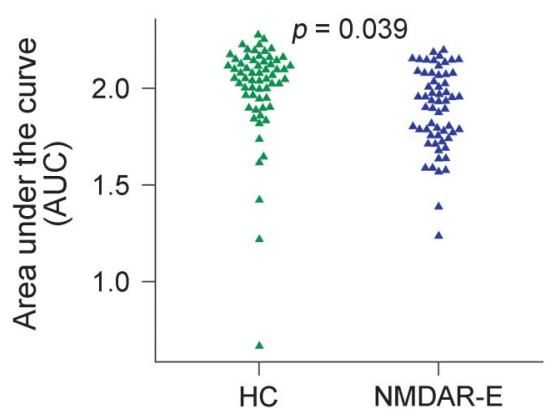

(A) Visual acuity measured according to Early Treatment Diabetic Retinopathy Study charts and (B) low contrast sensitivity tested using Functional Acuity Contrast Test (FACT) charts at photopic $(85 \mathrm{~cd})$ conditions compared between healthy controls $(\mathrm{HC})$ and patients with NMDA receptor encephalitis (NMDAR-E). Each dot represents 1 eye. detected with OCT. This is in line with cerebral MRI analyses that show alterations of functional connectivity despite normal routine imaging. ${ }^{8}$ OCT only assesses retinal changes, but afferent visual system affection might reside anterograde, e.g., in the optic nerve, optic radiation, or primary visual cortex. Retrograde transsynaptic degeneration has been shown in diseases such as multiple sclerosis, meaning that substantial neurodegeneration would also present in the retina. ${ }^{34}$ Furthermore, a previous study employing structural and functional resting-state MRI of patients after NMDAR encephalitis did not report any macroscopic alterations in the visual cortex. ${ }^{8}$

Second, the visual function deficit perhaps does not result from alterations in the afferent visual pathway, but at least in part from cortical processing deficits during visual testing. The previously reported functional and structural changes in patients after NMDAR encephalitis that involve extensive white matter damage support this hypothesis. ${ }^{8}$ Furthermore, a previous study in patients with multiple sclerosis showed that cognitive function impairment is associated with visual test results beyond affection of the afferent visual pathway. ${ }^{35}$ The difference between patients with no or mild and those with existing residual clinical impairment supports that this might be at least partially the case in our study. Cognitive impairment might also influence test scores in other ways. For example, cognitively impaired patients might be less likely to regularly update refraction.

The study had several limitations. The visual system assessments presented in this study were part of a comprehensive test battery, including neuropsychological testing and MRI. ${ }^{8,9}$ Due to the exploratory nature of this study, we were only able to include high-contrast VA and low-contrast sensitivity testing in addition to OCT and a basic neuro-ophthalmologic examination. To confirm 
A. Peripapillary retinal nerve fiber layer

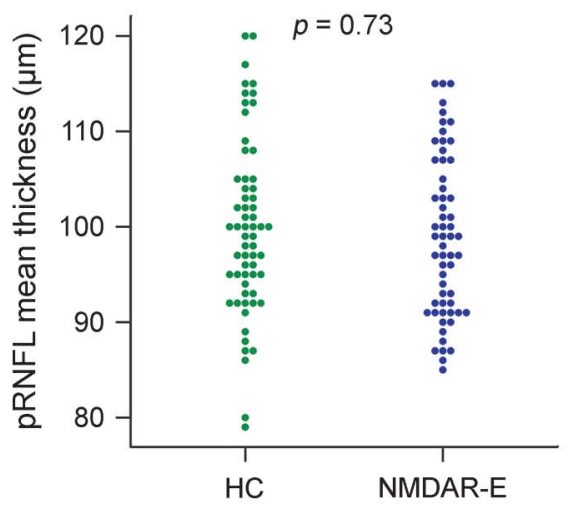

D. Outer plexiform and nuclear layer

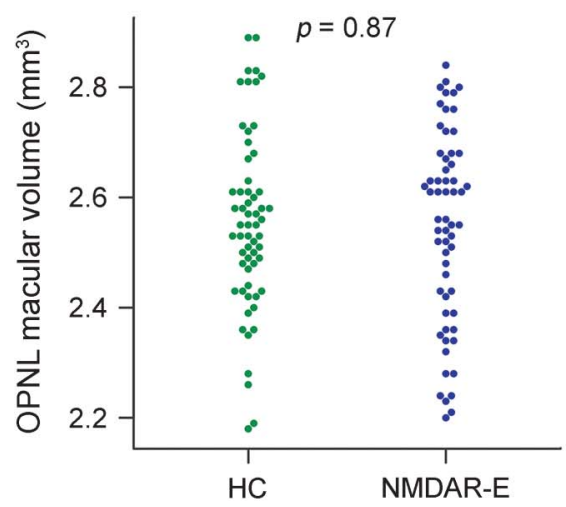

B. Ganglion cell complex

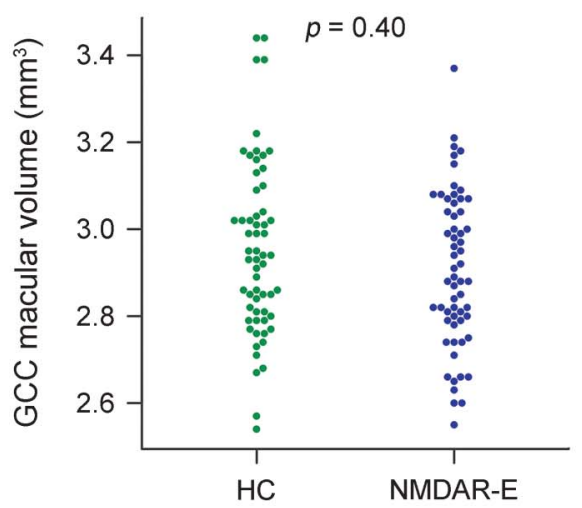

E. Photoreceptor layer

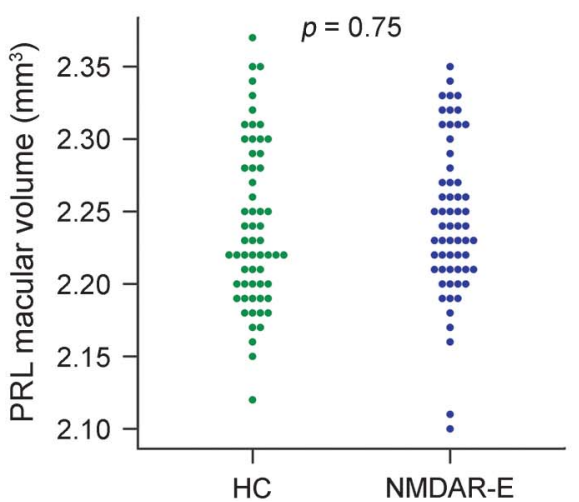

C. Inner nuclear layer

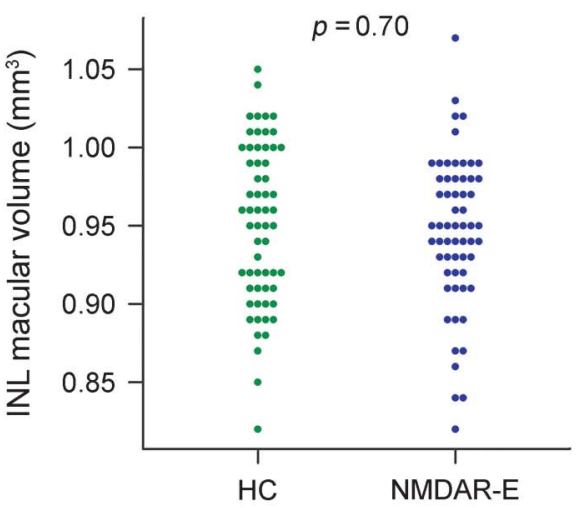

(A) Mean thickness in $\mu \mathrm{m}$ of the peripapillary retinal nerve fiber layer (pRNFL) and the volume in $\mathrm{mm}^{3}$ of the macular (B) ganglion cell complex (GCC), (C) inner nuclear layer (INL), (D) outer plexiform and nuclear layer (OPNL), and (E) photoreceptor layer (PRL). HC = healthy controls; NMDAR-E = NMDA receptor encephalitis.

and further elucidate the results of the study, electrophysiologic assessment of the optic nerve, tract, and radiation, as well as from the retina, would be necessary. Study participants only used habitual correction. As a result, we cannot rule out a potential bias introduced by insufficient refractory error correction. However, data distribution of high- and low-contrast FACT measurements and the reduction of all 5 spatial frequencies in low-contrast testing suggests that a potential refractory error bias could not sufficiently explain observed group differences. For low-contrast VA, further studies are needed to determine the extent to which deficits are caused either by high-contrast acuity deficits or affection of low-contrast visual perception. None of the patients reported visual dysfunction, and the reported mild VA deficits seem not to be relevant for an individual patient and instead were only statistically significant in a group comparison. The clinical relevance of visual function deficitsbeyond insight into the pathophysiology of the disease-therefore remains to be investigated.
In this study, we present preliminary evidence for visual dysfunction in patients recovering from NMDAR encephalitis. These functional changes were not based on detectable structural damage using OCT. The association between visual function and residual disability indicates that visual function may provide insight into general disease processes in NMDAR encephalitis. Potentially, visual function examination may provide information to the clinician about underlying changes in disease activity when performed longitudinally. Therefore, clarifying the clinical significance of visual dysfunction in NMDAR encephalitis warrants further investigation, including in longitudinal studies. Additionally, future studies should include electroretinography to assess potential functional retinal alterations.

\section{AUTHOR CONTRIBUTIONS}

Alexander U. Brandt: study concept and design, data interpretation, writing of the manuscript. Timm Oberwahrenbrock: statistical data analysis and interpretation, critical revision of the manuscript for intellectual content. Janine Mikolajczak: data acquisition, critical revision of the manuscript 
for intellectual content. Hanna Zimmermann: data quality control and postprocessing, critical revision of the manuscript for intellectual content. Harald Prüss: data acquisition, critical revision of the manuscript for intellectual content. Friedemann Paul: study supervision, critical revision of the manuscript for intellectual content. Carsten Finke: study concept and design, data acquisition, critical revision of the manuscript for intellectual content.

\section{ACKNOWLEDGMENT}

The authors thank the patients who participated in the study and James Ari Liebkowsky for proofreading the manuscript.

\section{STUDY FUNDING}

Supported by the German Research Foundation (DFG Exc 257 to F.P., DFG PR $1274 / 2-1$ to H.P.).

\section{DISCLOSURE}

A.U. Brandt served on the scientific advisory board for the Biogen VISION study; received travel funding and/or speaker honoraria from Novartis, Biogen, and Teva; has a patent bending for method and system for optic nerve head shape quantification; has consulted for Nexus and Motognosis; received research support from Novartis Pharma, Biogen Idec, BMWI, and BMBF; and holds stock or stock options in Motognosis. T. Oberwahrenbrock received speaker honoraria from Teva GmbH Germany and Bayer Germany. J. Mikolajczak received speaker honoraria from Teva GmbH Germany and Biogen Idec Germany. Hanna Zimmermann received speaker honoraria from Teva and Bayer. H. Prüss reports no disclosures. F. Paul is on the Novartis OCTIMS study steering committee and MedImmune steering committee; received travel funding and/ or speaker honoraria from Bayer, Novartis, Biogen Idec, Teva, SanofiAventis/Genzyme, and Merck Serono; is an Academic Editor for PLoS One; is an Associate Editor for Neurology ${ }^{\circledR}$ Neuroimmunology \& Neuroinflammation; has consulted for Sanofi Genzyme, Biogen Idec, and MedImmune; and received research support from Bayer, Novartis, Biogen Idec, Teva, Sanofi-Aventis/Genzyme, Merck Serono, German Research Council, German Ministry of Education and Research, BMBF Competence Network Multiple Sclerosis, Arthur Arnstein Stifung Berlin, Guthy Jackson Charitable Foundation, and the US National Multiple Sclerosis Society. C. Finke received research support from the Berlin School of Mind and Brain. Go to Neurology.org/nn for full disclosure forms.

Received October 5, 2015. Accepted in final form November 29, 2015.

\section{REFERENCES}

1. Dalmau J, Tüzün E, Wu H, et al. Paraneoplastic anti-Nmethyl-D-aspartate receptor encephalitis associated with ovarian teratoma. Ann Neurol 2007;61:25-36.

2. Dalmau J, Gleichman AJ, Hughes EG, et al. Anti-NMDAreceptor encephalitis: case series and analysis of the effects of antibodies. Lancet Neurol 2008;7:1091-1098.

3. Irani SR, Bera K, Waters P, et al. N-methyl-D-aspartate antibody encephalitis: temporal progression of clinical and paraclinical observations in a predominantly nonparaneoplastic disorder of both sexes. Brain 2010;133: 1655-1667.

4. Dalmau J, Lancaster E, Martinez-Hernandez E, Rosenfeld MR, Balice-Gordon R. Clinical experience and laboratory investigations in patients with antiNMDAR encephalitis. Lancet Neurol 2011;10:63-74.

5. Finke C, Kopp UA, Prüss H, Dalmau J, Wandinger KP, Ploner CJ. Cognitive deficits following anti-NMDA receptor encephalitis. J Neurol Neurosurg Psychiatry 2012;83: 195-198.

6. Titulaer MJ, McCracken L, Gabilondo I, et al. Treatment and prognostic factors for long-term outcome in patients with anti-NMDA receptor encephalitis: an observational cohort study. Lancet Neurol 2013;12: $157-165$
7. Heine J, Prüss H, Bartsch T, Ploner CJ, Paul F, Finke C. Imaging of autoimmune encephalitis: relevance for clinical practice and hippocampal function. Neuroscience 2015; 309:68-83.

8. Finke C, Kopp UA, Scheel M, et al. Functional and structural brain changes in anti-N-methyl-D-aspartate receptor encephalitis. Ann Neurol 2013;74:284-296.

9. Finke C, Kopp UA, Pajkert A, et al. Structural hippocampal damage following anti-N-methyl-D-aspartate receptor encephalitis. Biol Psychiatry Epub 2015 Feb 26.

10. Manookin MB, Weick M, Stafford BK, Demb JB. NMDA receptor contributions to visual contrast coding. Neuron 2010;67:280-293.

11. O'Dell TJ, Christensen BN. Horizontal cells isolated from catfish retina contain two types of excitatory amino acid receptors. J Neurophysiol 1989;61:1097-1109.

12. Eliasof S, Jahr CE. Rapid AMPA receptor desensitization in catfish cone horizontal cells. Vis Neurosci 1997; 14:13-18.

13. Slaughter MM, Miller RF. The role of excitatory amino acid transmitters in the mudpuppy retina: an analysis with kainic acid and N-methyl aspartate. J Neurosci 1983;3: 1701-1711.

14. Massey SC, Miller RF. Glutamate receptors of ganglion cells in the rabbit retina: evidence for glutamate as a bipolar cell transmitter. J Physiol 1988;405:635-655.

15. Hartveit E, Veruki ML. AII amacrine cells express functional NMDA receptors. Neuroreport 1997;8:1219-1223.

16. Dixon DB, Copenhagen DR. Two types of glutamate receptors differentially excite amacrine cells in the tiger salamander retina. J Physiol 1992;449:589-606.

17. Diamond JS, Copenhagen DR. The contribution of NMDA and non-NMDA receptors to the light-evoked input-output characteristics of retinal ganglion cells. Neuron 1993;11:725-738.

18. Mittman S, Taylor WR, Copenhagen DR. Concomitant activation of two types of glutamate receptor mediates excitation of salamander retinal ganglion cells. J Physiol 1990;428:175-197.

19. Hensley SH, Yang XL, Wu SM. Identification of glutamate receptor subtypes mediating inputs to bipolar cells and ganglion cells in the tiger salamander retina. J Neurophysiol 1993;69:2099-2107.

20. Cohen ED, Miller RF. The role of NMDA and nonNMDA excitatory amino acid receptors in the functional organization of primate retinal ganglion cells. Vis Neurosci 1994;11:317-332.

21. Aizenman E, Frosch MP, Lipton SA. Responses mediated by excitatory amino acid receptors in solitary retinal ganglion cells from rat. J Physiol 1988;396:75-91.

22. Massey SC, Miller RF. N-methyl-D-aspartate receptors of ganglion cells in rabbit retina. J Neurophysiol 1990;63: 16-30.

23. Titulaer MJ, Höftberger R, Iizuka T, et al. Overlapping demyelinating syndromes and anti-N-methyl-D-aspartate receptor encephalitis. Ann Neurol 2014;75:411-428.

24. Hacohen Y, Absoud M, Hemingway C, et al. NMDA receptor antibodies associated with distinct white matter syndromes. Neurol Neuroimmunol Neuroinflamm 2014; 1:e2. doi: 10.1212/NXI.0000000000000002.

25. Farrell B, Godwin J, Richards S, Warlow C. The United Kingdom transient ischaemic attack (UK-TIA) aspirin trial: final results. J Neurol Neurosurg Psychiatry 1991; 54:1044-1054. 
26. Bock M, Brandt AU, Kuchenbecker J, et al. Impairment of contrast visual acuity as a functional correlate of retinal nerve fibre layer thinning and total macular volume reduction in multiple sclerosis. $\mathrm{Br} \mathrm{J}$ Ophthalmol 2012;96:62-67.

27. Oberwahrenbrock T, Ringelstein M, Jentschke S, et al. Retinal ganglion cell and inner plexiform layer thinning in clinically isolated syndrome. Mult Scler 2013;19: 1887-1895.

28. Tewarie P, Balk L, Costello F, et al. The OSCAR-IB Consensus criteria for retinal OCT quality assessment. PLoS One 2012;7:e34823.

29. R Development Core Team. R: A Language and Environment for Statistical Computing [Internet]. Vienna, Austria: R Foundation for Statistical Computing; 2010. Available at: http://www.R-project.org.

30. Kruer MC, Koch TK, Bourdette DN, et al. NMDA receptor encephalitis mimicking seronegative neuromyelitis optica. Neurology 2010;74:1473-1475.
31. Cobo-Calvo Á, Izquierdo Gracia C, Quiñones SM, et al. Optic neuritis in the setting of NMDA receptor encephalitis. J Neuro-ophthalmol 2014;34:316-319.

32. Sawamura H, Yamamoto $T$, Ohtomo R, Bannai $T$, Wakakura M, Tsuji S. Anti-NMDA receptor encephalitis associated with transient cerebral dyschromatopsia, prosopagnosia, and lack of stereopsis. J Neuro-ophthalmol 2014;34:144-148.

33. Brandstätter JH, Hartveit E, Sassoè-Pognetto M, Wässle H. Expression of NMDA and high-affinity kainate receptor subunit mRNAs in the adult rat retina. Eur J Neurosci 1994;6:1100-1112.

34. Gabilondo I, Martínez-Lapiscina EH, Martínez-Heras E, et al. Trans-synaptic axonal degeneration in the visual pathway in multiple sclerosis. Ann Neurol 2014;75:98-107.

35. Wieder L, Gäde G, Pech LM, et al. Low contrast visual acuity testing is associated with cognitive performance in multiple sclerosis: a cross-sectional pilot study. BMC Neurol 2013;13:167. 


\section{Neurology \\ Neuroimmunology \& Neuroinflammation}

\section{Visual dysfunction, but not retinal thinning, following anti-NMDA receptor encephalitis}

Alexander U. Brandt, Timm Oberwahrenbrock, Janine Mikolajczak, et al.

Neurol Neuroimmunol Neuroinflamm 2016;3;

DOI 10.1212/NXI.0000000000000198

This information is current as of February 2, 2016

Updated Information \&

Services

References

Subspecialty Collections

Permissions \& Licensing

Reprints including high resolution figures, can be found at:

http://nn.neurology.org/content/3/2/e198.full.html

This article cites 33 articles, 4 of which you can access for free at: http://nn.neurology.org/content/3/2/e198.full.html\#\#ref-list-1

This article, along with others on similar topics, appears in the following collection(s):

Autoimmune diseases

http://nn.neurology.org//cgi/collection/autoimmune_diseases

Retina

http://nn.neurology.org//cgi/collection/retina

Visual loss

http://nn.neurology.org//cgi/collection/visual_loss

Information about reproducing this article in parts (figures,tables) or in its entirety can be found online at:

http://nn.neurology.org/misc/about.xhtml\#permissions

Information about ordering reprints can be found online: http://nn.neurology.org/misc/addir.xhtml\#reprintsus

Neurol Neuroimmunol Neuroinflamm is an official journal of the American Academy of Neurology.

Published since April 2014, it is an open-access, online-only, continuous publication journal. Copyright $(\subseteq$ 2016 American Academy of Neurology. All rights reserved. Online ISSN: 2332-7812.

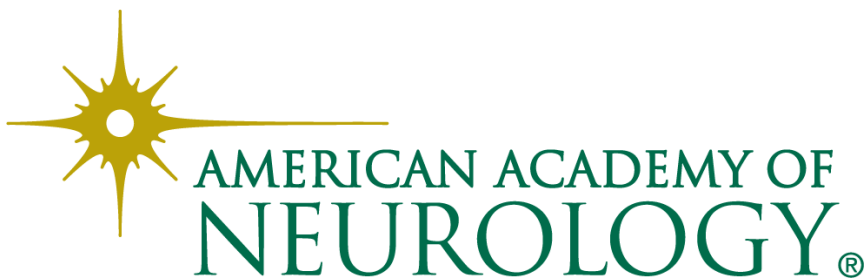

